\title{
Development of Local Food Products in Rejang Lebong According to Islamic Economics
}

\author{
Hendrianto*, \& Noza Aflisia \\ IAIN Curup, Bengkulu, Indonesia \\ * hendrianto@iaincurup.ac.id
}

\begin{tabular}{ll}
\hline Article Info \\
\hline Received & $: 2021-05-06$ \\
Accepted & $: 2022-01-12$ \\
Published & $: 2022-01-31$ \\
\hline
\end{tabular}

Key words: product; local food; marketing; islamic economics; islamic ethics

Abstract
This study aims to explore more deeply the strategies for obtaining
raw materials, diversification, and marketing of local food products
of Rejang Lebong and the ethics according to Islamic economics.
This qualitative descriptive study used data collection techniques in
the form of observation, interviews, and documentation. Meanwhile,
the data processing and analysis techniques used were descriptive
and analytic. The results showed that the strategy for obtaining raw
materials for local food production was by selecting quality raw
materials. Diversification of local food products of several forms,
namely Jantan Cookies, Vegetable Chips, and Krispi Petai.
Marketing of local food products of Rejang Lebong is carried out by
consignment, Direct Selling, Open Reseller, Online Shopping
Applications such as Blanja.com, Shopee, Bukalapak, Tokopedia,
social media such as Facebook, Instagram, Twitter, Youtube,
Website, Whatsapp, and Television. Meanwhile, ethics in the
development of local food products of Rejang Lebong according to
the Islamic economic perspective, namely being honest, accepting
criticism and suggestions from consumers, beneficial for others,
affordable prices, not vilifying other people's businesses, not
hoarding goods, not monopolizing, not selling haram goods, free
from the element of Riba, and without coercion.

\section{INTRODUCTION}

Local food is food produced from an area in Indonesia which is used as a characteristic of the area. The food in question is staple food and supplementary food that has been developed according to regional potential. Local food is defined as food products that have been produced and usually have a close relationship to the culture of the local community (Kadarwati, 2015). Local food is a food product that has long been produced, developed and consumed in an area or a certain local community group. Generally local food products are processed from local raw materials, local technology, and local knowledge. In addition, local food products are usually developed according to the preferences to local consumers as well. So that local food products are closely related to local local culture. Therefore, this product often uses regional names, such as gudeg jogja, garut dodol, Kudus Jenang, Cianjur rice, and so on (Hariyadi, 2014). Food will represent the uniqueness of a place. In particular, regional specialties are coupled with the uniqueness of their food products (Boonpienpon et al., 2015).

Currently, local food has been eroded by modern foods that have emerged. Modern food has been processed into various kinds of food and the pattern of people's consumption of local food has begun to shift. This requires the development of local food in order to increase nutrition, quality and variety in form so that it can compete with today's modern food. Awareness to develop local food products is not only the responsibility for the government but also the local community. With the development of local food products, food diversification can gradually be fulfilled because local food is the result of native Indonesian agriculture which is processed into various kinds of products. 
Indonesia is an agricultural country, there are many mountains and most of the areas of the population's livelihood are dominated by farming. Apart from high coffee productivity, regions in Indonesia, especially Rejang Lebong, are also the 6th largest coffee producer in Sumatra. This area is known as the granary for rice, vegetables, and tubers in Bengkulu Province. With a lot of raw materials for the development of local food products, it is appropriate for the government and society to always preserve it through policies and development by Micro, Small and Medium Enterprises in Indonesia (MSME). So that the development of local food products can also elevate the lives of farmers (Nandonde, 2016).

Fera Zahira's MSME is one of the Micro, Small and Medium Enterprises in Rejang Lebong and has been established since 2012 engaged in culinary and bakery fields. Then in 2015 he started producing regional souvenirs of Rejang Lebong, using abundant raw materials with local wisdom. MSMEs have succeeded in producing snacks with local food raw materials such as male banana which is produced into jantan cookies, spinach is produced into vegetable chips, and petai is produced into krispi petai. Jantan Cookies won 1st places in the Blueband Souvenir Master at the Bengkulu Province level, and also won local and national events. Jantan Cookies are one of the souvenirs of the 2017 Mister Indonesia event. In addition, there are also vegetable chips that have been covered by NET TV and national TV and the newest product produced is Krispi Petai. In the future, this MSME intends to market home industrial products of products marketed throughout Indonesia to overseas.

To run and develop a local food product business is certainly not easy. UMKM faced and passed obstacles, challenges and competition with precise strategies, starting from the process of obtaining raw materials to marketing. In every process that MSMEs go through without neglecting business ethics that should be applied because a business without ethics will bring destruction.

\section{LITERATURE REVIEW}

(Marsigit, 2010) in his research revealed that Bengkulu province has the potential for diversification of local processed food products which are quite diverse. Diversity is determined by the location of the source of the raw material, the dominant fishery products are in the coastal areas, the dominant food plants products come from the moderate plains, while the horticulture products are in the highlands.

Tubers are one of the potential food availability local foods which are very abundant and can grow in almost all regions in Indonesia. However, in some areas there has been a decrease in local food consumption such as these tubers and sago, including in areas that previously had food-based staple food patterns. local. During the period 1996 to 2011 consumption of sweet potatoes, cassava and sago decreased, while consumption of flour and its derivatives increased. As a result, the achievement of diversification of food consumption is still low (Hardono, 2016).

To accelerate the use of local food, real steps are needed from the local government, such as providing support in terms of transportation facilities and infrastructure for marketing agricultural products., support in the field of cultivation technology innovation for management at harvest time and after harvest, the formation of marketing networks of the development of partnership patterns of entrepreneurs and farmers as well as promotion or exhibition of local food products, growing home industries for processing various sago cakes and tubers, and from the aspect of the giver community development, capital assistance and training are needed for farmers to increase the use of agribusiness-oriented local food (Sunanto, et al., 2019). The results of training are not always applicable and immediately successful, but require repeated training, as is done in making chips or sale (Saugi \& Sumarno, 2015).

Various local food products can develop if with the right strategy, Utami and Dumasari found that the strategy for developing local processed food products made from cassava in 
Banyumas Regency is to always maintain the taste and characteristics of local products and forming agribusiness cluster areas (Utami \& Dumasari 2014). To increase the competitiveness of local products of modern products carried out by the creative industry in Bandar Sribawono sub-district, the first are with an intensive strategy (market penetration, market development, product development). The second strategy are to provide quality products of different taste variances according to consumer desires. Then the pricing strategy is to set prices that are not high for consumers. The development strategy is to promote through brochures and social media (Farida, 2018). Meanwhile, the strategy in developing sweet skin syrup agro-nutrition in the Kerinci area is by increasing the amount of production according to the availability of raw materials, in addition to developing this business also working with the Kerinci Regency government as partners (Ismaya et al.. 2015.).

Small and Medium Enterprises Snack Barokah develops business in ways including utilizing packaging machines, producing snacks, increasing the quality of products produced, obtaining additional capital through government credit programs, maintaining price levels and improving quality taste, product promotion is carried out through electronic media, expanding the market by visiting wholesalers, and maintaining good relations of all suppliers (Zulkarnaen \& Sutopo, 2013).

Almost all of these studies tend to be local food products, solid food sources of carbohydrates, while what will be studied is ole. $\mathrm{h}$ this researcher is the development of local food products of Rejang Lebong area that is more varied and more creative in the form of snacks with modern flavors, namely made from bananas, vegetables and petai so that the development of local food products is more updating and in this research also looks at carried out business ethics and conformity with Islam.

Looking at the previous research there is a discussion that emphasizes more on the use of raw materials available in the regions, but does not discuss the form of marketing and production ethics in accordance with Islamic sharia, even though Islam has provided good and correct procedures in the development of local food. This research will explore further and deeper regarding the development of local food products according to Islamic economics. The purpose of this research is to explain (1) strategies to obtain raw materials, (2) types of product diversification, (3) forms into product marketing, and (4) to analyze ethics in the development of local food products of Rejang Lebong according to the Islamic economic perspective.

\section{METHODS}

The procedures and methods of a study do not stand alone but are part of the suspicions, questions and practices that is currently prevailing over society (Aflisia, et al., 2021). This research is a field research using a qualitative descriptive approach. The researcher intends to try to describe and describe in detail the business ethics and development strategies of local food products of Rejang Lebong. Researchers approach the object of research to obtain the required information on interviews and observations. The researcher interprets the implied and implied meanings of the interaction between interviews and field observations.

The primary data sources of this study are the owners of MSMEs Jantan Cookies, Vegetable Chips, and Krispi Petai, employees who help with the production, promotion and distribution processes, as well as consumers of Jantan Cookies, Vegetable Chips, and Krispi Petai. Meanwhile, secondary data comes from written documentation such as books, articles and social media related to this research.

This study uses data collection techniques in the form of observation, interviews, and documentation. The researcher used the observations in this study to obtain data onto production, distribution and promotion of male cookies, vegetable chips, and Krispi petai, so that the ongoing business ethics could be identified so that their conformity with Islamic business ethics could be identified. Interviews were conducted to collect data onto strategies to 
obtain raw materials for production, product diversification and marketing strategies for local food products in Rejang Lebong. Meanwhile, documentation is one of the data collection techniques to obtain written data onto Cookies, Vegetable Chips, and Krispi Petai Products. Documentation is also done by studying archives or documents, photos, books related to the object of research.

The data analysis technique used in this research is the following stages:

First, processing and preparing the data onto analysis.

At this stage the researcher has prepared data onto strategies for obtaining raw materials for local food products, strategies for developing local food products, and good business ethics from the results of interviews, observations, and documentation. The data is then arranged into types according to the source of information.

Second, reading the entire data

Researcher builds a general sense of the data and information that has been obtained and reflects on it, such as the general ideas contained in what the participants say, the tone of the idea, the impression of credibility, and the narrative of the information.

Third, start coding all the data.

Code that are developed when analyzing text transcripts or images are grouped into three categories, namely, First, codes related to the main topics that are commonly known. Second, shocking and unexpected code at the start of the study. Third, codes that is odd and have conceptual interest.

Fourth, Perform coding to describe the setting, people, categories and themes analyzed Researchers associate themes in a series of stories or develop these themes into a theoretical model.

Fifth, to describe the themes that will be presented again in the narrative / qualitative report.

Discussions about the chronology of events, themes, or about the relationship between themes.

Sixth, interpreting and interpreting the data.

Researchers reveal the essence of an idea and answer what lessons and conclusions are drawn from all the data that has been obtained.

\section{RESULTS AND DISCUSSION}

\section{Strategies to Get Raw Materials for Local Food Production in Rejang Lebong}

Competition for food and food production tools has increased, without increasing the supply of raw materials commensurate with (Abdelhady, 2012). Competing is good as long as the way is in accordance with Islamic principles, as Islam also recommends healthy competition (Hendrianto \& Ridwan, 2021). To produce a product that is popular with the market and is in demand by many people, there are many things that must be considered. Starting from how to get raw materials, the production process, to promotion and marketing. The most basic thing related to a product's raw material is the quality of the raw material itself. With good quality raw materials and processed by professional hands, it can produce products that are liked by many people.

Choosing quality raw materials is done by sorting, namely selecting raw materials that are not defective and have the right level of maturity. This is important to do to produce quality products. In addition, raw materials are collected a maximum of 2 days before production so that production runs smoothly and the resulting product is in accordance with expectations in form and quality. Then before selling the product of consumers, it has gone through Quality Control so that the product that reaches the consumer can be enjoyed properly without feeling disappointed in taste, shape and price. 
The capital needed to meet the needs of raw materials depend on the desired production capacity for a nominal value of around Rp. 2,000,000. Each day can produce up to 50 packs of food products and in one month approximately 500 packs are sold out.

The raw materials needed to produce snacks such as male cookies, vegetable chips, and krispi petai are such as male bananas, mustard greens, carrots, tomatoes, broccoli, and petai. These raw materials are processed together with other selected spices so that the raw materials of Rejang Lebong produce are successfully transformed into modern food with delicious flavors.

Abundant raw materials are found in Bengkulu Province, Rejang Lebong Regency, especially Sumber Bening Village, Selupu Rejang District. Raw materials are not obtained directly from farmers but are obtained in the market through traders and collectors. With fertile and cool natural conditions with abundant harvests, the raw materials do not need to be imported from outside Rejang Lebong. This has always been maintained by MSMEs, in addition to doing business, they also enliven local wisdom through local food products in the area.

The activity of obtaining raw materials sometimes results in obstacles due to the harsh weather and season. During the dry season, many fruit and vegetable farmers experience crop failures. This has an impact on local food production made from fruit and vegetables. Not only that, the activity of obtaining raw materials was also constrained when farmers did not harvest at that time. This can happen usually when farmers have other activities in the community such as mutual cooperation, wedding parties, tahlilan, and so on. This activity is time-consuming and causes farmers to delay harvesting for some time.

Raw materials are the life in producing a product. Without raw materials, production activities cannot run. Whether or not the quality of the raw materials controls the taste of the resulting product. For that, raw materials absolutely exist in production activities. No matter the season or the weather is not favorable, production must go on. Although limited raw materials often occur.

To get around the limitations of raw materials, a strategy is needed, namely by storing raw materials in the freezer so that they last a long time and do not significantly reduce the quality of these raw materials. This strategy has proven to be successful in making production run smoothly, without being interrupted due to limited or no raw materials. However, when raw materials are completely unavailable, the production process has to be temporarily stopped, and when the raw materials are abundant in the market, products are produced in large quantities and then marketed to various regions in Indonesia.

\section{Diversification of Local Food Products in Rejang Lebong}

Inspired by products produced by MSMEs on the island of Java, Fera Zahira has succeeded in producing various types of snacks made from local produce such as Jantan Cookies, Vegetable Chips, and Krispi Petai. To produce various types of products, it takes about a year to observe raw materials, market tests, and so on. 


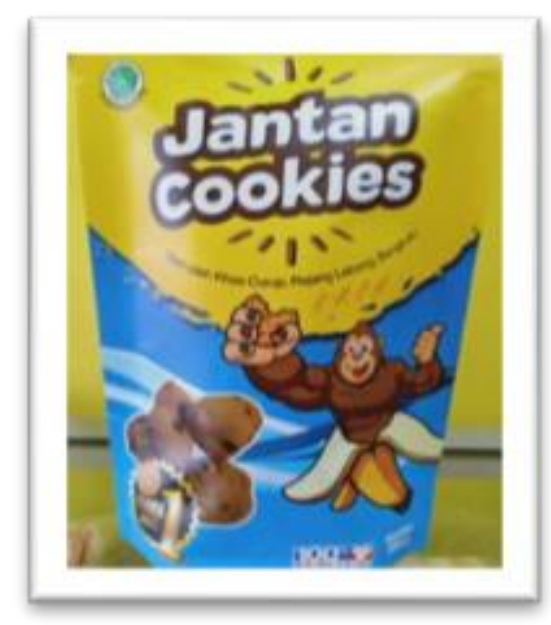

Figure 1. Jantan Cookies

Jantan Cookies are the most popular snack food by consumers, with a delicious, crunchy and sweet taste that is just right. This bread-like dry food is often referred to as a cookie, which is made from male bananas, a choice typical of regions in Rejang Lebong, which are processed properly and professionally to produce quality cookies, contain potassium bananas that are good for the body, and are very suitable to be eaten as a casual snack with your beloved family. with friends at work or travel, cakes for Eid, become regional souvenirs in Rejang Lebong for beloved relatives and so on.

Besides the taste that invites the taste buds of Jantan Cookies, Cookies are also the easiest product to find raw materials in this particular area of Rejang Lebong. This area is bestowed by Allah SWT with fertile land and is very supportive of the development of plantations such as growing vegetables and fruits. Various vegetables and fruits produced by vegetable and fruit farmers. Among these types of bananas are male bananas which are very suitable to be processed into a variety of foods.

Armed with abundant raw materials and delicious flavors, Jantan Cookies won First Place in the Blueband Souvenirs Masters at the Bengkulu Province level and also won local and national snack events. Jantan Cookies are also a souvenir souvenir at the Mister Indonesia event in 2017.

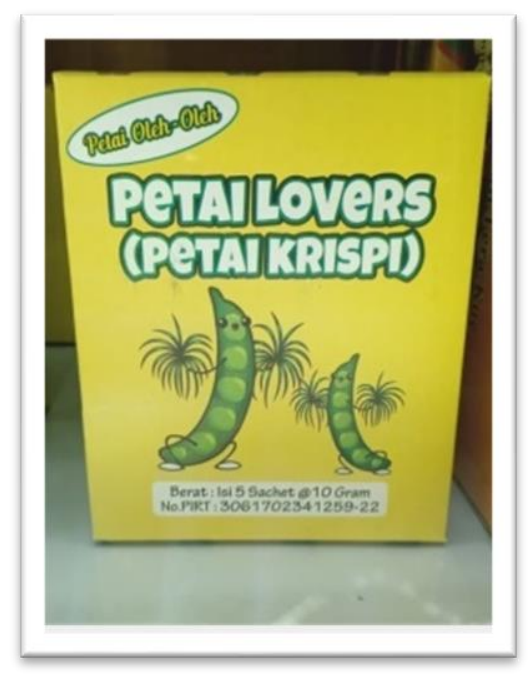

Figure 2. Krispi Petai 
Unlike the case with Jantan Cookies, Krispi Petai Products in getting raw materials are not as easy as getting male bananas. But it doesn't hinder the production process. Raw materials are in the sufficient category for the public to enjoy and can be produced into other processed products. Petai krispi is made from original raw materials from local crops in Rejang Lebong. Petai is fried until crispy with a delicious taste and not greasy, suitable for sprinkling various chili sauce, curry, and fried rice.

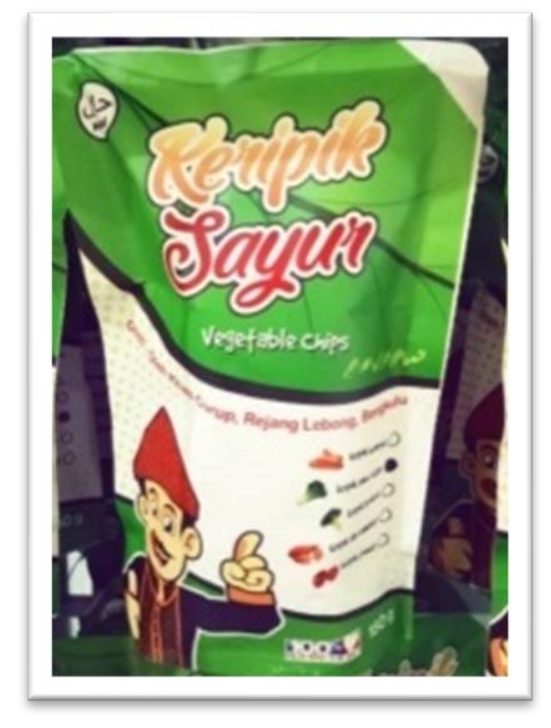

Figure 3. Vegetable Chips

The products produced by regional MSMEs in Rejang Lebong are vegetable chips. Chips are made from vegetables from Rejang Lebong crops such as broccoli, tomatoes, mustard greens, yams, and kale. The five variants of these vegetables have been transformed into delicious, crunchy, and nutrient-rich vegetable chips. Enjoying these vegetable chips can be any time and is most suitable as a snack for people who don't really like eating vegetables. The bestselling chips in the market are vegetable chips with tomato variants.

The three food products produced are becoming increasingly popular with their participation in competitions inside and outside the city of Bengkulu. So that food products are increasingly recognized by everyone and all circles. Orders also came from various people and regions.

Sales have penetrated out of town, of course not with a small turnover. The turnover of product sales in a normal month reaches a figure in the range of $\mathrm{Rp}$. 25,000,000 to Rp. $30,000,000$ with profits ranging from Rp. $8,000,000$ to Rp. 10,000,000. However, there is a decline in the current atmosphere of the Pandemic Coronavirus disease 19 (Covid 19). The selling price of each Male Cookies product is Rp. 20,000, - Spinach Chips for Rp. 15,000, - and Krispi Petai for Rp. 35,000. For retail or wholesale purchases, get the same price.

There is a change in the number of requests that usually occur before the month of Ramadan, Eid, and New Year. At that time the price has increased from the previous price.

Currently, MSMEs are still developing product distribution at the national level. In this development, there are several strategies carried out to achieve predetermined targets, namely (1) in collaboration with gift shops, hypermarts, and resellers. (2) participating in the National Competition so that it is widely known by the public and at the same time as a promotional media. 


\section{Marketing of Local Food Products in Rejang Lebong}

Changing demographics and purchasing power of Muslim consumers and the success of Muslim entrepreneurs have started to make Islamic marketing a scientifically and managerial attractive field (Sandikci, 2011). Snack food products such as Jantan Cookies, Spinach Chips, and Krispi Petai have been widely marketed since 2016. After a year earlier, they started production and are marketed only in the regions. The production started from participating in the Provincial level Souvenir Master competition, to making MSMEs more engaged, continuing to produce, and developing the snack products they had.

One of the efforts in product development is to target marketing not only to focus on the regions but by surviving, starting to spread to neighboring cities. Even today, the marketing of Jantan Cookies, Vegetable Chips, and Krispi Petai products has reached the Province of South Sumatra, namely the Lubuk Linggau, Jambi, Lombok and Jakarta areas. Marketing is carried out to all souvenir shops and hypermart in the city and province. Consumers who are the target of marketing these food products are not only local people, but also tourists, governments, and the general public throughout Indonesia and abroad.

The strategies carried out in the sale of Male Cookies, Vegetable Chips, and Krispi Petai are as follows:

First, Consignment

Consignment is a way of selling a product with a system of cooperation between the product owner and the shop (distributor). MSME entrusts the food it produces, namely Jantan Cookies, Vegetable Chips, and Krispi Petai at gift shops and Hypermarts in and out of town. The distributor then sells the product that was deposited above the price set by the producer. The dealer only pays for the number of items sold at the agreed price. The excess obtained by the dealer is the advantage that belongs to the distributor.

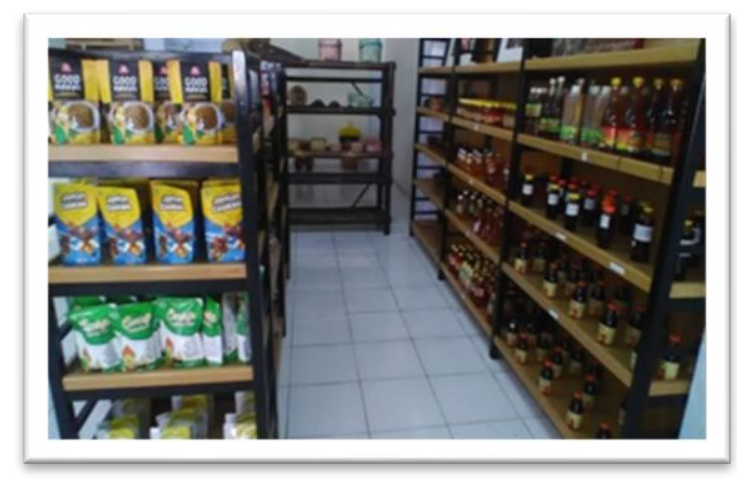

Figure 4. Gift Shop

Second, Direct Selling

Direct Selling, which is a sales system carried out by product owners by directly meeting and dealing with buyers. The producer sells the food it produces by opening a simple shop at his house, namely Jl. Gajah Mada Raya No. 79, Air Rambai, Curup, Rejang Lebong, Bengkulu, Indonesia. Buyers can come directly to the shop if they want to enjoy the food they produce. 


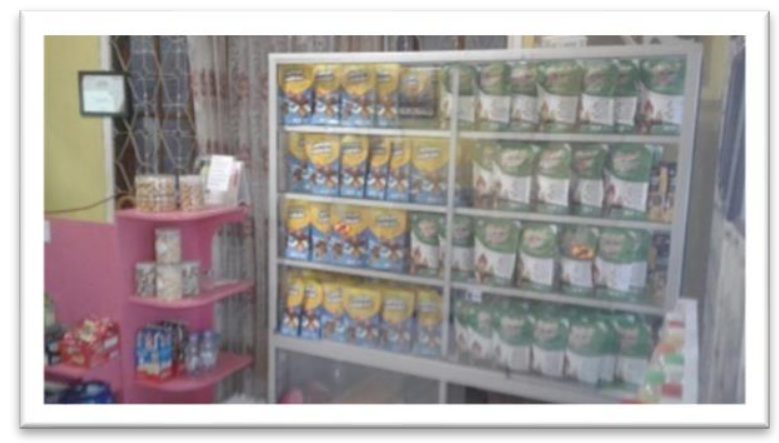

Figure 5. MSME

Third, Resellers

In selling snack products that they produce, MSMEs also open resellers for those interested in reselling food products that they have produced.

Fourth, Online Shopping Application

Online Shopping Application is also called the Marketplace, namely online applications that are used as a medium for buying and selling a product. The online shopping applications used by MSMEs are as follows:

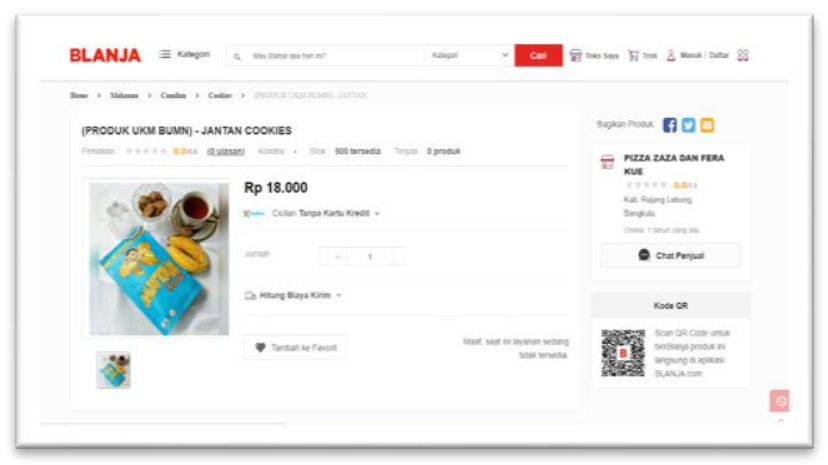

Figure 6. Blanja.com

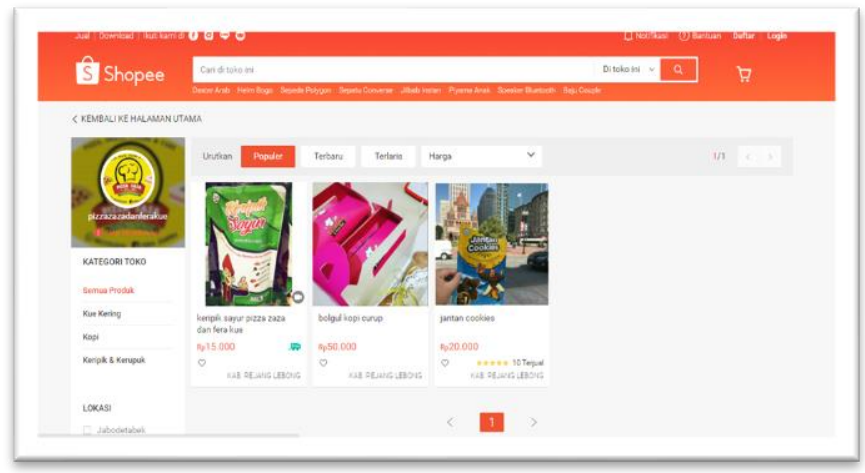

Figure 7. Shopee 


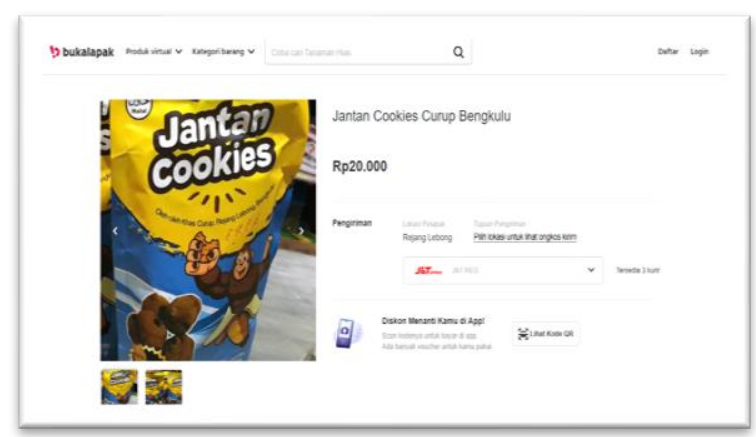

Figure 8. Bukalapak

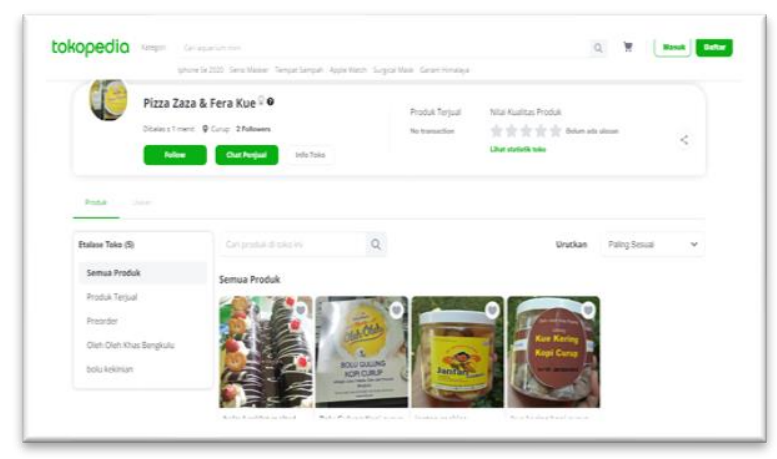

Figure 9. Tokopedia

Fifth, social media

The use of social media apart from being a promotional media as well as a media that initiates buying and selling for food product owners. The food products that are produced are promoted on social media so that they can be seen by other social media users, who are then interested in tasting and buying food products. Transactions can be made via bank account transfers or via online motorcycle taxis, where money is entrusted to an online motorcycle taxi which is trusted to deliver the food. So even though there is no face-to-face meeting between the seller and the buyer. Transactions can still be executed.

The social media used by MSMEs in the promotion and sale of Jantan Cookies, Vegetable Chips, and Krispi Petai are as follows:

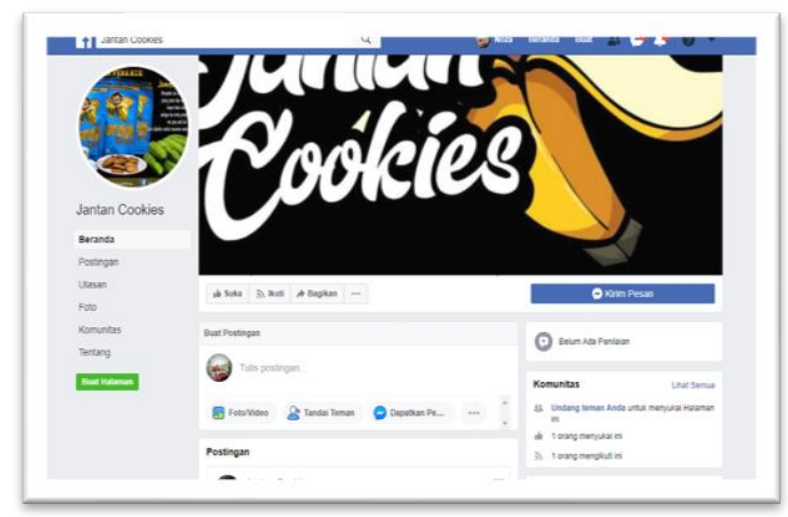

Figure 10. Facebook 


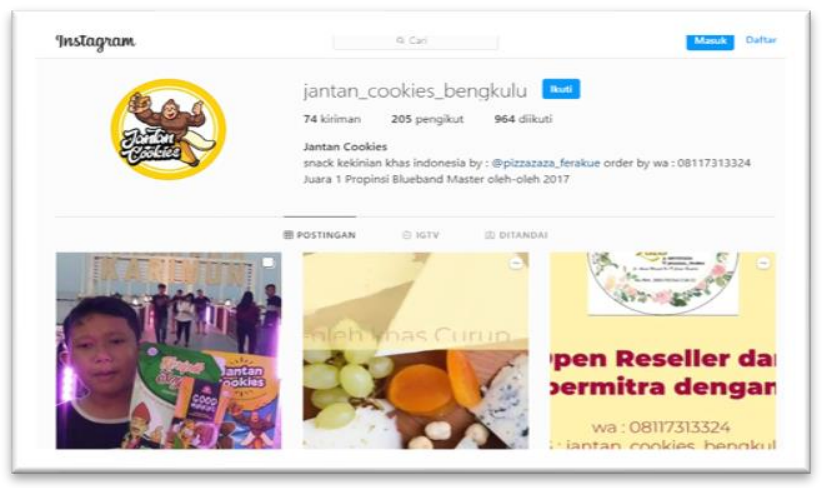

Figure 11. Instagram

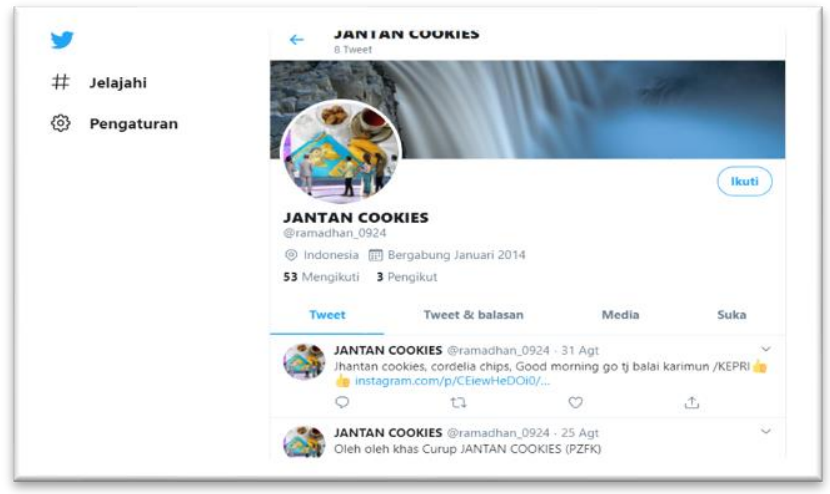

Figure 12. Twitter

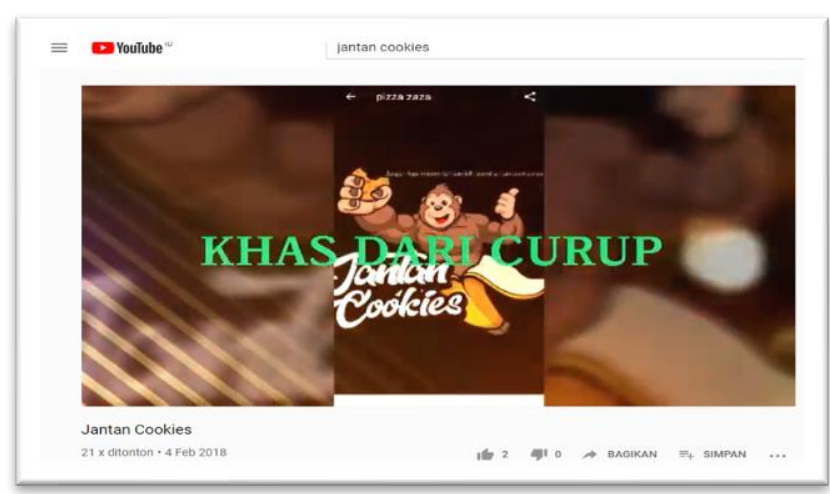

Figure 13. Youtube

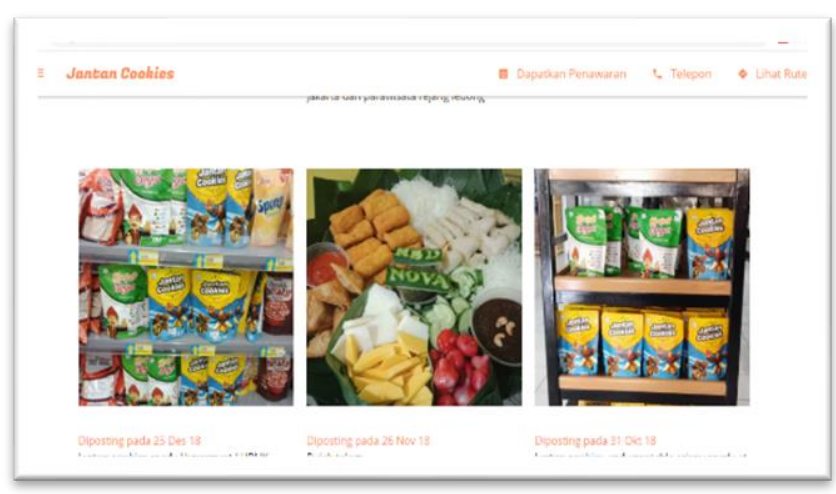

Figure 14. Website 
In addition, television media are also used such as Whatsapp, Television (Net 10), and other local media. Among the many media, the one that most influences consumers is the promotion carried out through the social media Facebook so that there are purchases by consumers in large numbers.

In an activity it does not always run smoothly, of course it encounters obstacles, as well as in the production of this food, namely the difficulty in marketing products outside the Bengkulu Province, due to shipping costs which are not cheap and are not comparable to the price of the snack products purchased. This has made the marketing of Jantan Cookies, Vegetable Chips, and Krispi Petai products not maximized. This is not only a problem for the products of one MSME, but all the Curup SME products are not able to go national because there is no policy to reduce shipping costs.

\section{Ethics for the Development of Local Food Products in Rejang Lebong According to Islamic Economic}

Islam is a religion that regulates everything related to human life. Both the problem of human relations with God (Hablun min Allah), and human relations with fellow humans (Hablun min Al-Nas) (Hendrianto \& Elfalahy, 2021). The human relationship with Allah is related to the worship of a servant to the Creator. To carry out Hablun min Allah as well as possible, namely by carrying out all the commands and rights of Allah and not associating Him with others. The real practice is by doing the prayers, fasting, and so on. Meanwhile, Hablun min Al-Nas, namely relationships with fellow humans such as giving shadaqah, having good character with fellow humans, advising in kindness and patience, connecting with friendship and so on.

Islamic economics is based on Islamic belief-based principles, namely the Quran and Hadith (Iqbal \& Mirakhor, 2013), Because Islam has a main concept based on the kalam of Allah and Hadith (Hendrianto et al., 2021), which will find solutions to the problems of the modern world (ElMassah, 2015). The goal of economics in Islam is to enhance happiness for body and soul, namely physical well-being and inner peace (Syamsuri \& Saputro 2018), and to achieve socio-economic justice (Hassan \& Salman, 2018). One of the relationships between humans and fellow humans that is regulated in Islam is a form of social amaliyah such as muamalah. Muamalah is the relationship between humans and fellow humans which is related to the development of property such as buying and selling, borrowing and lending, and renting. All of these things must be carried out in accordance with the Islamic law that Allah has determined in the Quran and through the Hadith of the Prophet Muhammad.

Allah makes it possible for people to conduct world affairs that are believed to be able to benefit the people while paying attention to Islamic ethics (Aflisia, et al., 2021). As well as with Muamalah activities such as buying and selling practices, especially in the development of local food products, must always pay attention to Islamic ethics, namely the ethics taught and applied by the Prophet Muhammad. This ethic must be carried out by all parties involved, from production actors, employees, sellers, to buyers. Likewise, every activity must always apply Islamic ethics, starting from production, distribution, to sales to consumers.

The Islamic ethics contained in the development of local food products by MSMEs are as follows:

First, honest.

Consumers should get information related to products clearly and honestly, and according to what they are, so that consumers lose their doubts about these products. Things like this are applied by Fera Zahira's MSMEs, namely explaining related information from product specifications according to actual conditions such as what raw materials are used to make these foods, production dates and levels of resistance. The owner / seller tries his best in providing information to consumers so that there is no misinformation.

Second, accepting consumer criticism and suggestions 
Mistakes and mistakes in acting are part of human nature, because humans are not free from mistakes. For this reason, prudence in acting is the concern of MSMEs. In order to minimize deficiencies and errors in food production, MSMEs always provide time to hear complaints from consumers. These consumer complaints are sought for solutions to product improvements in the next production.

Third, useful for others.

In principle, consumers are part of the utilization of production results. So producers must produce nutritious and useful products. Various foods produced by UMKM are made from vegetables and fruits which are good for the human body, nutritious, and healthy. It can be consumed by all people from children to adults and its halalness is guaranteed.

Fourth, affordable prices

Abundant raw materials make regional MSMEs have no difficulty in obtaining materials. Many raw materials at an affordable price. Therefore, the MSMEs set prices that are affordable and not too expensive, let alone to the detriment of consumers. Affordable prices affect consumers who initially only want to taste, then repeat orders, and become regular customers, even recommending others to enjoy the food.

Fifth, not to discredit other people's businesses.

Business cannot be separated from the existence of competition, both product competition, place, price, and promotion. Competition in Islam has certain limitations such as not badmouthing other people's businesses. In this case, MSMEs have shown a healthy and good form of competition, because they do not bad-mouth other people's businesses. MSMEs solely highlight the advantages of products to others with various efforts to provide creativity to innovate.

Sixth, not hoarding goods

Limited raw materials sometimes occur and this is normal. Sometimes there are producers to control the limitations of these raw materials with hoarding, thus making the surrounding community limited in obtaining materials. It is different from MSMEs which always pay attention to the quality of fresh raw materials. Collect raw materials according to short-term needs for several production times. If the collection is more than that, it is feared that the material will be damaged, rotten, and the surrounding community will experience limitations in obtaining the material.

Seventh, do not do monopoly

Doing monopoly makes it difficult for people to get a product and the price of the product can be played by producers. This makes consumers forced to buy these products. As it is known, Rejang Lebong has a variety of snack variants that can be the choice of consumers. MSMEs make innovation and creativity from these snacks so that they have a different taste from the others.

Eighth, not selling haram goods

In Islam, not all goods or food are allowed to be consumed and sold (Adams, 2011). According to the majority of Muslim jurists selling anything that comes from pork is haram, be it meat, fat, etc. that comes from pork and then mix it into food (Fadzlillah et al., 2011) (Hussain \& Routray, 2012). For this reason, the food sold is halal food (Alserhan, 2016). Halal affects consumer confidence in food, either through advertisements, information on food ingredients and announcements, various Halal claims (Rezai, et al., 2012), including obtained halal certificates. To obtain halal assurance for a local food product, MSMEs have registered their products with the Indonesian Religious Leader to obtain a halal certificate. Evidence of the halalness of a product is very important to obtain so that consumers don't worry about the product being produced. 


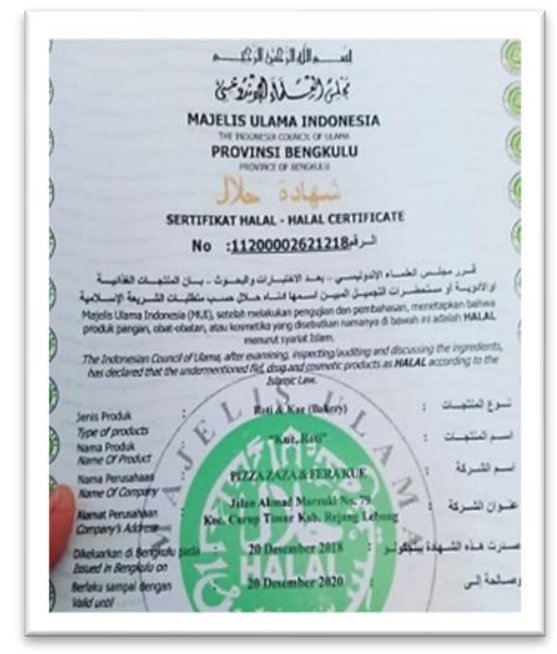

Figure 15. MUI Halal Certificate

The product has been produced and obtaining a halal certificate does not guarantee good, sometimes the product has experienced damage to taste and shape (expired). Things like this are not traded by MSMEs. Even consumers admit that they have never encountered expired food products that are sold by MSMEs. All of this is done to get the good of consumers and owners / sellers.

Ninth, free from the element of Riba.

The general term riba means exaggerating the amount of principal, regardless of the amount (Khan, 2020); (Mulawarman, 2011); (Uddin, 2011); (Mustofa, 2018). Riba transactions must be abandoned (Ali, et al., 2013) because usury is strictly prohibited in Islam, namely taking extras that are done impulsively. MSMEs try to be careful in business in order to avoid riba. The forms of MSME prudence include various stages, both initial capital, management, to buying and selling transactions. All are free from Riba.

Tenth, without coercion.

Consumers are also known as kings who have the right to endeavor (choose) which ones they like and which they don't like. This gives MSMEs the freedom to choose from the three products that have been prepared, such as Jantan Cookies, Vegetable Chips, and Krispi Petai.

Eleventh, pay wages immediately

For every company that employs other people, they must pay the wages of the workers before their sweat dries, that's what the Prophet Muhammad ordered. If the payment has been determined, do not break the agreement that has been agreed upon. MSMEs always pay attention to their employees, especially in terms of wages, in providing wages, each employee is paid monthly based on mutual agreement.

Twelfth, Good and friendly service

Excellent service is part of seller ethics in an effort to develop local food products that give good impressions to consumers. MSMEs provide good and friendly service, in this case it is felt directly by consumers when they enter the shop, they are immediately greeted in a friendly manner then offer various good quality local food products with various variants of shapes and flavors.

Thirteenth, intelligent employees

To run MSMEs and develop them is to involve smart employees. Good service ethics, honesty, neat clothes, mastering the products sold and polite speech reflect the intelligence possessed by 
UMKM employees. Likewise with employees who have duties in the production department, produce well and professionally.

The application of Islamic values in the development of a product will not only bring benefits to producers but also bring blessings. The combination of benefits and blessings obtained by producers is a maslahah that will contribute to the achievement of falah (Setiyowati, et al., 2020).

\section{CONCLUSIONS}

Development of local food products in Rejang Lebong is carried out with a strategy of selecting quality raw materials, processing time and method. Then produce various forms of local food such as Jantan Cookies, Vegetable Chips, and Krispi Petai. Marketing and all activities with attention to Islamic values, both in consignment, Direct Selling, Open Reseller, and Online Shopping Applications. The results of this study will open space for future researchers to look further and deeper into local food in Rejang Lebong from various perspectives, such as exportimport inflation and the development of local food production, the use of the latest technology in processing local food raw materials, and so on. So that, in order to obtain a diverse picture related to local food in Rejang Lebong.

\section{Suggestion}

For further researchers, it is hoped that they can conduct deeper studies related to local food products that are not only specifically for the Rejang Lebong area but also the Indonesian territory so that local wisdom is preserved in the midst of today's modern times. This study has limitations that can affect the results of the study, namely the results of the study depending on the honesty of the respondents interviewed, in addition to researchers also conducting observations and documentation as data collection. In addition, this study only discusses local food development only on marketing and ethics, so researchers further need to examine more broadly, such as capital adequacy and raw material control. With this research, it is expected to contribute by making it as a guideline related to marketing and ethics in the development of local food products available in an area.

\section{REFERENCES}

Abdelhady, H. (2012). Islamic Finance as a Mechanism for Bolstering Food Security in the Middle East:Food Security Waqf. Sustainable Development Law \& Policy, 13 (1). https://doi.org/10.4197/Islec

Adams, I. A. (2011). Globalization: Explaining the Dynamics and Challenges of the Halāl Food Surge. Intellectual Discourse, 19(1), 123-145. https://journals.iium.edu.my/intdiscourse/index.php/id/article/view/184

Aflisia, N. ., Ahmad E.Q, N. ., \& Suhartini, A. (2021). The Urgency of Theological Foundations in Islamic Education in the Industry Era 4.0 towards the Society Era 5.0. International Journal of Education Research and Development, 1(1), 60-77. https://doi.org/10.52760/ijerd.v1i1.4

Aflisia, N., Alie, A. A., \& Haryanti, E. (2021). Critical Study of the Modern Science Epistemology. Asian Journal of Multidisciplinary Research \& Review (AJMRR), 2(1), 1-21. https://thelawbrigade.com/wp-content/uploads/2021/04/AJMRR Noza-Aflisia-AnangAzharie-Alie-Erni-Haryanti.pdf

Ali, L., Ali, A., \& Khwaja, H. (2013). Comparison of Islamic and Conventional Banking on the Basis of Riba and Services: A Case Study of Peshawar Region. International Review of Management and Business Research, 2(3), 837-846. https://www.irmbrjournal.com/paper details.php?id=171 
Alserhan, B. A. (2016). The Principles of Islamic Marketing. The Principles of Islamic Marketing, 2, 260. https://doi.org/10.4324/9781315553948

Boonpienpon, N., Maneenetr, T., Siriwong, P., \& Kovathanakul, D. (2015). Indigenous Islamic Food: An Ideal Product Innovation for Creativity in Cultural Tourism: A Case Study Khao Tung Pla (Thai Crispy Rice Crackers with Anchovies). Mediterranean Journal of Social Sciences, 6(5), 445-453. https://doi.org/10.5901/mjss.2015.v6n5s2p445

Fadzlillah, N. A., Che Man, Y. B., Jamaludin, M. A., Ab Rahman, A., \& Al-kahtani, H. A. (2011). Halal Food Issues from Islamic and Modern Science Perspectives. In International Conference on Humanities, Historical and Social Sciences, 17,159-63. Singapore. https://www.academia.edu/download/58894982/Halal_Food_Issues_from_Islamic.pdf

Farida, L. (2018). Analisis Strategi Pengembangan Produk Pangan Lokal Dalam Meningkatkan Industri Kreatif Perspektif Ekonomi Islam. http://repository.radenintan.ac.id/5121/

Hardono, G. S. (2016). Strategi Pengembangan Diversifikasi Pangan Lokal. Analisis Kebijakan Pertanian, 12(1), 1-17. https://doi.org/10.21082/akp.v12n1.2014.1-17

Hariyadi, P. (2014). Pengembangan Industri Pangan Sebagai Strategi Diversifikasi Dan Peningkatan. In Seminar Nasional Sains Dan Teknologi, 8-17.

Hassan, R., \& Salman, S. A. (2018). Islamic Accountability and Waqf towards Achieving Equitable Distribution of Wealth within the Islamic Economic Framework. nternational Journal of Islamic Economics and Finance Research, 1(1), 1-11. http://ijiefer.kuis.edu.my/ircief/article/view/1

Hendrianto, H., \& Elfalahy, L. (2021). Ayat-Ayat Hukum Dalam Alquran Mengatur Hubungan Sesama Manusia. Al-Istinbath : Jurnal Hukum Islam, 6(1), 165-178. https://doi.org/10.29240/jhi.v6i1.2719

Hendrianto, H., Juhaya S. Praja, \& Nurrahman. (2021). Sharia Philosophy Correlation and the Islamic Economic Philosophy. Economit Journal: Scientific Journal of Accountancy, Management and Finance, 1(1), 12-20. https://doi.org/10.33258/economit.v1i1.370

Hendrianto, H., \& Ridwan, A. (2021). Dampak Negatif Jual Beli Barang Di Atas Penawaran Orang Lain. I-ECONOMICS: A Research Journal on Islamic Economics, 7(1), 11-22. https://doi.org/https://doi.org/10.19109/ieconomics.v7i1.7915

Hussain, A. \& Routray, J.K. (2012). Status and factors of food security in Pakistan. International Journal of Development Issues, 11(2), 164-185. https://doi.org/10.1108/14468951211241146

Iqbal, Z., \& Mirakhor, A. (2013). Economic Development and Islamic Finance. Economic Development and Islamic Finance. https://doi.org/10.1596/978-0-8213-9953-8

Ismaya, R., Napitupulu, D., \& Malik, A. (2015). Analisis Strategi Pengembangan Agroindustri Sirup Kulit Manis Di Kabupaten Kerinci. Jurnal Ilmiah Sosio-Ekonomika Bisnis, 18(1), 43 53. https://doi.org/10.22437/jiseb.v18i1.2815

Kadarwati, M. L. (2015). Tingkat Pengembangan Dan Daya Tahan Bolu Kukus Berbahan Dasar Tepung Singkong (Manihot Esculenta Crantz) Yang Disubstitusi Tepung Kacang Hijay (Phaseolus Radiatus). Acta Universitatis Agriculturae et Silviculturae Mendelianae Brunensis, 16(2),39-55. https://doi.org/10.1377/hlthaff.2013.0625

Khan, M. A. (2020). Riba in Islamic Finance: Some Fresh Insights. Journal of Economic and Social Thought, 7(1), 25-40. http://www.kspjournals.org/index.php/JEST/article/view/2037 
Marsigit, W. (2010). Pengembangan Diversifikasi Produk Pangan Olahan Lokal Bengkulu Untuk Menunjang Ketahanan Pangan Berkelanjutan. Agritech, 30(4), 256-264.

https://jurnal.ugm.ac.id/agritech/article/view/9717

ElMassah, S. (2015). Islamic Economy Option: SWOT Case Study Analysis. Advances in Management \& Applied Economics, 5(3), 63-84.

https://papers.ssrn.com/sol3/papers.cfm?abstract_id=2748141

Mulawarman, A. D. (2011). Elimination of Riba Through Tazkiyah (Purification) of the Cash Flow Concept: A Study the Indonesian Islamic Business Habitus. In 9th Annual International Conference on Business: Accounting, Finance, Management \& Marketing, 4-7 July 2011, Athens, Greece., 1-19. https://www.academia.edu/download/36497413/mulawarman_athens_2011.pdf

Mustofa, L. (2018). The Substance of the Formal Prohibition of the Riba: Islamic Finance and the Tie with the Real Economy. IJISH (International Journal of Islamic Studies and Humanities), 1(1), 56. https://doi.org/10.26555/ijish.v1i1.134

Nandonde, F. A. (2016). Integrating of Local Food Suppliers in Modern Food Retail in Africa: The Case of Tanzania. Aalborg Universitetsforlag. Ph.d.-serien for Det Samfundsvidenskabelige Fakultet, Aalborg Universitet https://doi.org/10.5278/vbn.phd.socsci.00059

Rezai, G., Mohamed, Z., \& Shamsudin, M. N. (2012). Assessment of Consumers' Confidence on Halal Labelled Manufactured Food in Malaysia. Pertanika Journal of Social Science and Humanities, 20(1), 33-42. http://psasir.upm.edu.my/id/eprint/40363/1/09\%20Pg\%2033$\underline{42 . p d f}$

Sandıkcı, Ö. (2011), Researching Islamic marketing: past and future perspectives. Journal of Islamic Marketing, 2(3), 246-258. https://doi.org/10.1108/17590831111164778

Saugi, W., \& Sumarno, S. (2015). Pemberdayaan Perempuan Melalui Pelatihan Pengolahan Bahan Pangan Lokal. Jurnal Pendidikan Dan Pemberdayaan Masyarakat, 2(2), 226-238. https://doi.org/10.21831/jppm.v2i2.6361.

Setiyowati, A., Azqiya, K., \& Umriyah. (2020). The Behavior of Islamic Producer in Supplying Halal Food at Laziza and Waroeng Steak and Shake Surabaya. Advances in Social Science, Education and Humanities Research, 436, 117-121. https://doi.org/10.2991/assehr.k.200529.024

Sunanto, S., Salim, S., \& Rauf, A. W. (2019). Analisis Kesepakatan Peningkatan Produktivitas Kopi Arabika Pada Pengembangan Kawasan Di Kabupaten Toraja Utara. Jurnal Sosial Ekonomi Pertanian, 15(1), 42-55. https://doi.org/10.20956/jsep.v15i1.6369

Syamsuri, S., \& Saputro, Y. E. (2018). Panca Jiwa as Social Capital Approach: An Alternative Strategy for Islamic Economic Development. Share: Jurnal Ekonomi Dan Keuangan Islam, 7(2), 180-203. https://doi.org/10.22373/share.v7i2.2668 .

Uddin, Md, A. (2011). Principles of Islamic Finance: Prohibition of Riba, Gharar and Maysir MPRA Munich Personal RePEc Archive, 5(5), 1763-1767. https://mpra.ub.uni$\underline{\text { muenchen.de/67711/ }}$

Utami, P., \& Dumasari. (2014). Strategi Pengembangan Usaha Bisnis Pangan Lokal Olahan Ubikayu Di Kabupaten Banyumas. Agritech, 16(2), 129-138. http://jurnalnasional.ump.ac.id/index.php/AGRITECH/article/view/1026 .

Zulkarnaen, H. O., \& Sutopo. (2013). Analisis Strategi Pemasaran Pada Usaha Kecil Menengah (UKM) Makanan Ringan (Studi Penelitian UKM Snack Barokah Di Solo).http://eprints.undip.ac.id/40138/ 